\title{
Analysis of Factors Affecting Firm Value with Intellectual Capital as Moderating Variable in Kompas 100 Companies Listed on the IDX
}

\author{
Muhammad Fahriza Tampubolon ${ }^{1}$, Erlina $^{1}$, Khaira Amalia Fachrudin ${ }^{1}$ \\ ${ }^{1}$ Department of Accounting, Faculty of Economics and Business at Universitas Sumatera Utara, Indonesia
}

Corresponding Author: Muhammad Fahriza Tampubolon

\begin{abstract}
The purpose of this study was to determine and examine the influence of factors that affect firm value. The factors include firm size, profitability, leverage, asset structure, liquidity, and company growth tested on companies listed in the Kompas 100 Stock Company and test whether the intellectual capital can moderate the relationship between the independent variable and the dependent variable. This research is causal research using secondary data.

The population of this study is companies that are members of the Kompas 100 Stock Company listed on the Indonesia Stock Exchange from 2016 to 2019. The sampling method used is Purposive Sampling, so that there are 71 companies in 4 years of research so that 284 observations are obtained. The analytical technique used in this study is panel data regression analysis and tested for moderating with the Eviews ten software tool.

The results of this study partially firm size and liquidity have a negative and insignificant effect on firm value; profitability, leverage, and firm growth have a positive and significant effect on firm value partially; and asset structure has a negative and significant effect on firm value. The intellectual capital variable does not moderate the relationship between firm size, profitability, leverage, asset structure, liquidity and firm growth on firm value.
\end{abstract}

Keywords: firm size, profitability, leverage, asset structure, liquidity, firm growth, intellectual capital, firm value

\section{INTRODUCTION}

The company is carrying out its operational activities to maximize its value (Fatimah, Mardani, \& Wahono, 2019). Firm value is the price that prospective buyers are willing to pay if the company is sold (Brigham \& Houston, 2006). A high company value makes the interest of investors even greater because it shows that the company can provide high returns for shareholders (Wijaya \& Sedana, 2015).

Nurhayati (2013) said that one way to measure company value is to use the Price to Book Value (PBV) ratio. PBV is the ratio between the market value of shares and the book value of the company's equity. The rise and fall of company value in the capital market is an interesting phenomenon to discuss. In this study, the firm value was measured using Price to Book Value (PBV). The following is the average PBV for Kompas 100 shares in 2016-2019 which can be seen in Figure 1.:

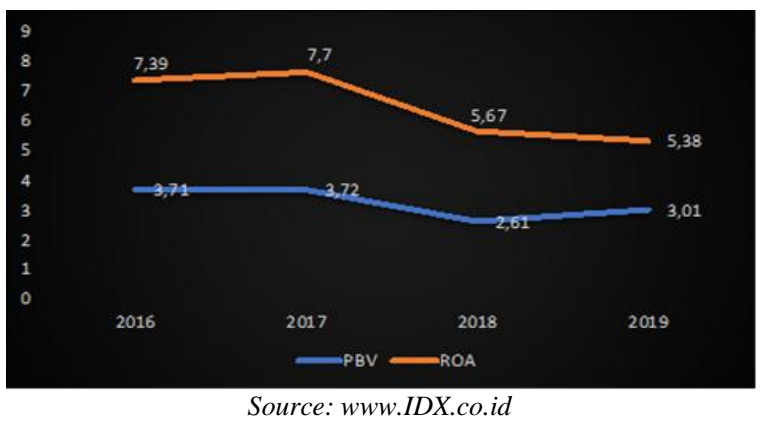

Figure 1. Average PBV and ROA of Kompas 100 Companies in 2016-2019 
We can see in Figure 1. wherein 2017, there was an increase in ROA from 7.39 to 7.7. Then in 2018, it fell to 5.67 and again, there was a decline to 5.38 in 2019. However, the value of the company in 2019 increased from 2.61 to 3.01. It is not following the signalling theory. According to (Prayitno 2007), PBV describes how much the market appreciates the book value of a company's shares. The higher this ratio means the market believes in the company's prospects. According to signalling theory, the benefits of disclosing financial statement information will provide a positive signal to investors about the state of the company's financial performance. According to this theory, when the company's Profitability is high, it will give confidence to potential investors about profitable prospects in the future to increase the company's value (Hermungsingsih \& Wardani, 2009).

Company size is the size of a company in terms of total assets, total sales, total profit, tax expense and others (Brigham \& Houston, 2018). Yao (2011) states that the bigger a company is, the more stakeholders will highlight it. The company's size will affect the funds obtained from the capital market because investors will have more confidence in companies with large company sizes (Sintyana \& Artini, 2019). The bigger a company, the more it wants to get recognition and good judgment from the community. Investors in their capital participation also need to look at the size of the company. The company's size is considered capable of influencing its value because the larger the size or scale of the company, the easier it will be for companies to obtain sources of funding, both internal and external (Prasetyorini, 2013). So large companies tend to have large investment potential, which then encourages the company's value to increase.

Chairir (2015) states that Profitability is the company's ability to generate profits and measure operational efficiency and efficiency in using its assets. The greater the Profitability, the higher the value of the company. The profitability ratio is a ratio to assess the company's ability to seek profit (Kasmir, 2011). In this study, Profitability will be measured using Return on Assets (ROA). ROA is one indicator of the company's success to generate profits, so the higher the Profitability, the higher the company's ability to generate profits (Rachmawati, 2012). High Profitability will signal investors that the company is in a favourable condition or can earn profits in generating a return on its capital. It is an attraction for investors to own shares of the company. The high demand for shares will make investors provide a share price greater than the value recorded on the company's balance sheet (Purnama, 2016). However, according to pecking order theory, companies with large profit levels have larger internal funding sources and have a smaller need for external funding (Hermuningsih, 2012).

According to Harahap (2013), leverage is a ratio that describes the relationship between the company's debt to capital. This ratio can see how far the company is financed by debt or external parties with the company's ability described by capital. The trade-off theory states that when the capital structure is below the optimum point, any additional debt will increase the company's value. Otherwise, if the capital structure is above the optimum point, any additional debt will reduce the company's value. (Limbong \& Chabachib, 2016). The leverage ratio used in this study is the ratio of total debt to equity, namely the debt to equity ratio (DER). Increasing the level of leverage means that the level of uncertainty of return is getting higher (Indriyatni, 2012).

Asset structure is a balance or comparison between fixed assets and total assets (Manoppo, 2018). Asset structure determines how much funds are allocated for each asset component, both current and fixed assets (Dessyana, 2016). Companies often use fixed assets as collateral to convince external parties to get loans, 
making it easier for companies with large fixed assets to get loans (Manoppo, 2018).

Liquidity is the company's ability to meet the company's short-term obligations. Companies with a high level of liquidity tend to use internal funding sources to fund their operational activities to have low debt (Dessyana, 2016). Liquidity describes the ability of a company to meet its financial obligations that must be fulfilled immediately (Nugroho, 2012). Liquidity will affect the size of the dividend, which describes the company's cash flow. The greater the available cash, the better the company's liquidity.

High liquidity will illustrate that the company is in good condition, so that it will increase the company's stock price, which will have an impact on increasing company value (Taw \& Susilo, 2017). In this study, liquidity is proxied using the current ratio (CR), which describes the company's ability to pay short-term obligations or those that mature within one year. It will describe the company's state in maximizing assets to meet current liabilities and other debts so that it becomes important for investors as a reference in making investment decisions (Jihadi et al., 2021).

The company's total assets growth is either an increase or decreases experienced during a period (one year). Asset growth will affect the profit generated by the company to impact increasing company value (Carstens \& Wesson, 2019). Growth is expressed as growth in total assets where past asset growth will describe the company as having aspects that benefit investors where the rate of return on investment will go well (Dewi \& Sudiartha, 2017).

Intellectual capital is an intangible asset that can provide value to the company, including intellectual property rights, patents, copyrights, and franchises (Olivia \& Hatane, 2015). Intellectual Capital is considered an economic value creator for companies oriented towards long-term sustainable growth (Kartika, 2013). Providing information to investors about intellectual capital will provide an overview to investors about the quality of human resource performance. When human resources are high, it will certainly affect the company's size because it will improve its financial performance so that it impacts increasing the company's value.

Intellectual capital will create added value, which will improve employee performance and financial performance. It will certainly affect the company's profitability. The higher the intellectual capital of the company, the higher the value of the company, which will give a positive signal to investors about the company's performance.

Disclosure of intellectual capital information will benefit the organization because it will provide information to investors in knowing the quality of its resources. When the intellectual capital is high, it will impact its profit to affect its financing in terms of debt payments. In other words, it can affect leverage.

Intellectual capital will have an impact on the company's financial quality. The higher the intellectual capital, the higher the Profitability, so that it will increase the company's asset structure, which impacts increasing the company's value. Liquidity can be affected by Intellectual Capital because Intellectual Capital will affect profits, which will impact liquidity. The higher the Intellectual Capital, the higher the liquidity.

Disclosure of intellectual capital is very important because it can provide information to investors about the company's human resources. Investors will be more confident investing in companies with high human resources because they believe the funds invested will be managed. It will impact increasing company profits properly because when the company experiences an increase in profits, it will affect increasing the company's size, which will impact increasing profits. The value of the company.

This research was conducted on companies that are members of the Kompas 100 stock. The researcher chose the Kompas 
100 stock as the object of research because the Kompas 100 stock company is an index that measures the price performance of 100 stocks that have good liquidity and large market capitalization (Kompas, 2021). In addition, Kompas 100 shares are also classified as bluechip companies that should also have quality human resources but are also still experiencing a decline in Profitability (ROA).

Based on the phenomenon of fluctuations in PBV and Profitability and inconsistent research results, the researchers are interested in researching with the title "Analysis of Factors Affecting Firm Value Using Intellectual Capital as Moderating in Compass 100 Stock Companies Listed on the Indonesia Stock Exchange".

\section{Previous Research Review}

Several previous studies have researched this topic, and there are differences in research results. Prasetyorini (2013) shows that firm size has a positive effect on firm value. These results are supported by research by Rudangga \& Sudiarti (2016), Hutasoit (2016), and Sari and Priyadi (2016). However, research conducted by Limbong \& Chababib (2016) and Suwarno et al. (2016) states that firm size has a negative and insignificant effect on firm value. Research conducted by Purnama (2016) shows that Profitability has a significant effect on firm value. These results are in line with research from Nugroho (2012) and Shalini (2020). However, this result contradicts the research of Rahayu \& Sari (2018), which shows that Profitability does not affect firm value. Research conducted by Sutama and Lisa (2018) shows that leverage affects firm value. These results align with Khumairoh et al. (2016) and Pratama and Wiksuana (2016). In contrast to the research conducted by Prasetyorini (2013) and Novari and Lestari (2016), which showed that leverage did not affect firm value.

The research results by Setiadharma and Machali (2017) and Pamungkas et al. (2020) show that asset structure affects firm value. The research results by Mahendra (2012) and Rompas (2013) show that liquidity affects firm value. In contrast to the results of research by Shalini (2020), which states that liquidity does not affect firm value. Research by Kusumajaya (2011) and Noerirawan and Muid (2012) shows that company growth significantly affects firm value. Research by Sari and Dwiranda (2019), Setiawati and Lim (2018) and Wibowo and Yuliana (2020) shows that intellectual capital can moderate the effect of Profitability on firm value.

\section{Framework}

Following the description of the background of the problem, literature review and previous research, a conceptual research framework is prepared as follows:

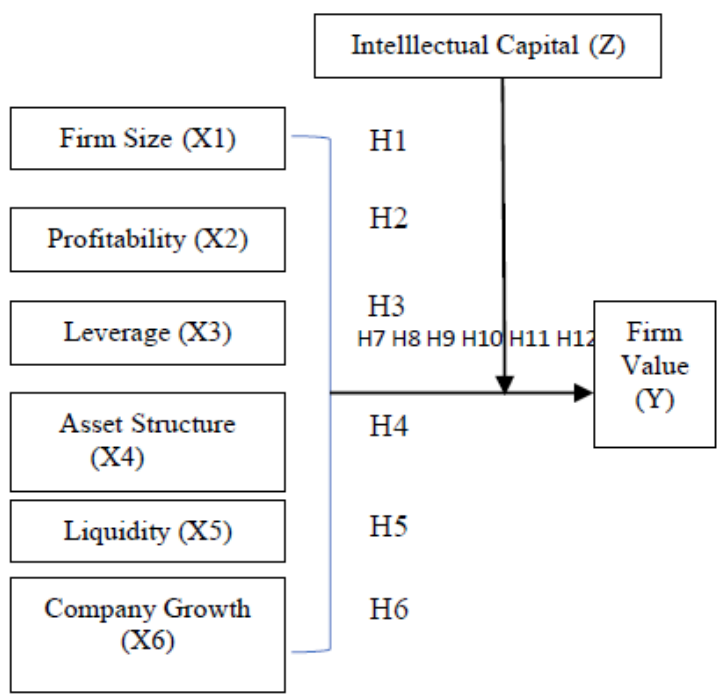

Figure 2. Conceptual Framework

H1: Firm size has a significant effect on Firm Value.

H2: Profitability has a significant effect on Firm Value.

H3: Leverage has a significant effect on Firm Value.

H4: Asset structure has a significant effect on Firm Value.

H5: Liquidity has a significant effect on Firm Value.

H6: Company growth has a significant effect on Firm Value. 
H7: Intellectual Capital can moderate the effect of Firm Size on Firm Value.

H8: Intellectual Capital can moderate the effect of Profitability on Firm Value.

H9: Intellectual Capital can moderate the effect of Leverage on Firm Value.

H10: Intellectual Capital can moderate the influence of Asset Structure on Firm Value.

H11: Intellectual Capital can moderate the effect of Liquidity on Firm Value.

H12: Intellectual Capital can moderate the effect of Company Growth on Firm Value.

\section{RESEARCH METHODS}

This type of research is causal associative research to determine the effect of Firm Size, Profitability, Leverage, Asset Structure, Liquidity, and Company Growth as independent variables on Firm Value as the dependent variable with Intellectual Capital as the moderating variable. The causal associative study analyses the relationship between one variable to determine how one affects other variables (Erlina, 2011). The data analysis method used in this study is a statistical analysis method using the EViews application. Data analysis performs by testing standard assumptions and testing hypotheses.

The populations used in this study were 100 companies that are members of the Kompas 100 Stock listed on the IDX in 2016-2019. Using the purposive sampling technique, a sample of 71 companies was obtained multiplied by four years of research to obtain 284 observations.

\section{RESULT AND DISCUSSION Normality Test}

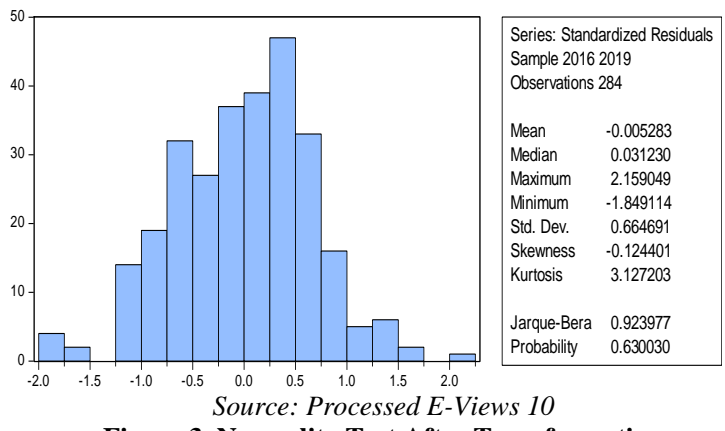

Figure 3. Normality Test After Transformation
Based on the picture above, it can be concluded that the probability value of 0.630030 is greater than 0.05 , which indicates that the data is normally distributed. So that further testing can be carried out.

\section{Panel Data Regression Model Estimation}

To analyze panel data, the thing that must be done is to analyze the Common Effect Model (CEM), Fixed Effect Model (FEM) and Random Effect Model (REM) to determine the appropriate model to use.

\section{Common Effect Model Test}

Table 1. Common Effect Model Estimation Results

\begin{tabular}{|l|l|l|}
\hline Variables & Coefficient & Prob. \\
\hline $\mathrm{C}$ & -0.503093 & 0.0578 \\
\hline $\mathrm{X} 1$ & 0.011489 & 0.1162 \\
\hline $\mathrm{X} 2$ & 7.149224 & 0.0000 \\
\hline $\mathrm{X} 3$ & 0.178218 & 0.2542 \\
\hline $\mathrm{X} 4$ & 0.239980 & 0.1517 \\
\hline $\mathrm{X} 5$ & 0.008193 & 0.6205 \\
\hline $\mathrm{X} 6$ & $-0,121291$ & 0.0269 \\
\hline \multicolumn{2}{|c|}{ Source: Processed E-Views 10} \\
\hline
\end{tabular}

From the regression results of common effect models, it is concluded that firm size, profitability, leverage, asset structure, and liquidity positively affect firm value partially. In contrast, firm growth has a negative effect on firm value.

\section{Fixed Effect Model Test}

Table 2. Fixed Effect Models Estimation Results

\begin{tabular}{|l|l|l|}
\hline Variables & Coefficient & Prob. \\
\hline $\mathrm{C}$ & 0.609621 & 0.3550 \\
\hline $\mathrm{X} 1$ & -0.017497 & 0.4673 \\
\hline $\mathrm{X} 2$ & 4.467301 & 0.0000 \\
\hline $\mathrm{X} 3$ & 0.453574 & 0.0198 \\
\hline $\mathrm{X} 4$ & -0.479316 & 0.0179 \\
\hline $\mathrm{X} 5$ & -0.017272 & 0.3718 \\
\hline $\mathrm{X} 6$ & 0.075203 & 0.0119 \\
\hline \multicolumn{2}{|c|}{ Source: Processed E-Views 10} \\
\hline
\end{tabular}

From the regression results of fixedeffect models, it is concluded that Profitability, leverage, and company growth positively affect firm value partially. Company Size, Asset Structure, and Liquidity have a negative influence on the Company Value partially. 
Muhammad Fahriza Tampubolon et.al. Analysis of factors affecting firm value with intellectual capital as moderating variable in Kompas 100 companies listed on the IDX.

\section{Random Effect Model Test}

Table 3. Random Effect Models Estimation Results

\begin{tabular}{|l|l|l|}
\hline Variables & Coefficient & Prob. \\
\hline $\mathrm{C}$ & 0.157770 & 0.6389 \\
\hline $\mathrm{X} 1$ & -0.005045 & 0.6356 \\
\hline $\mathrm{X} 2$ & 5.929258 & 0.0000 \\
\hline $\mathrm{X} 3$ & 0.277465 & 0.0866 \\
\hline $\mathrm{X} 4$ & -0.196829 & 0.2504 \\
\hline $\mathrm{X} 5$ & -0.011141 & 0.5077 \\
\hline $\mathrm{X} 6$ & 0.076017 & 0.0069 \\
\hline
\end{tabular}

From the estimation results of random effect models, it is concluded that Profitability, Leverage, and Company Growth positively influence Firm Value partially. Company Size, Asset Structure, and Liquidity have a negative influence on the Company Value partially.

\section{Panel Data Regression Model Selection}

There are three tests carried out to decide which model to use: the Chow Test, Hausman Test, and Lagrange Multiplier Test.

\section{Chow Test}

\begin{tabular}{|l|l|l|l|} 
Table 4.Chow Test Results \\
\begin{tabular}{|l|l|l|l|}
\hline Effects Test & Statistic & d.f. & Prob. \\
\hline Cross-section F & 8.490247 & $(70,207)$ & 0,0000 \\
\hline
\end{tabular} \\
\hline
\end{tabular}

The table above shows that the probability value of 0.0000 is smaller than 0.05, so the Fix Effect Model (FEM) is better than the Common Effect Model (CEM).

\section{Hausman Test}

Table 5. Hausman Test Estimation Results

\begin{tabular}{|l|l|l|l|}
\hline Test Summary & $\begin{array}{l}\text { Chi-Sq. } \\
\text { Statistic }\end{array}$ & $\begin{array}{l}\text { Chi-Sq. } \\
\text { d.f. }\end{array}$ & Prob. \\
\hline $\begin{array}{l}\text { Cross-section } \\
\text { random }\end{array}$ & 12.733341 & 6 & 0.0475 \\
\hline \multicolumn{4}{|c|}{ Source: Processed E-Views 10} \\
\hline
\end{tabular}

The table above shows that the probability value $=0.0475$ is greater than 0.05 , so the model that is feasible to use is the Fixed Effect Model (FEM).

\section{Hypothesis Test}

Hypothesis testing in this study using the estimation results of the Random Effect Model (REM) regression model.

\section{Coefficient of Determination Test}

Table 6. Coefficient of Determination Test Results

\begin{tabular}{|l|l|}
\hline R-squared & 0.843052 \\
\hline Adjusted R-squared & 0.785429 \\
\hline S.E. of regression & 0.395429 \\
\hline F-statistic & 32.36737 \\
\hline Prob(F-statistic) & -94.57962 \\
\hline \multicolumn{2}{|c|}{ Source: Processed E-Views 10} \\
\hline
\end{tabular}

Based on the table above, it can be seen that the value of Adjusted R Square is 0.785429 . It indicates that the role or contribution of the independent variables, namely company size, Profitability, leverage, asset structure, liquidity and company growth, can explain the dependent variable, namely company value is $78 \%$. In comparison, the rest, $22 \%$, is explained by other variables.

\section{Partial Test (t-Test)}

\begin{tabular}{|l|l|l|l|}
\multicolumn{5}{l}{ Table 7.Partial Test Results } \\
\hline Variables & Coefficient & t-Statistic & Prob. \\
\hline C & 0.609621 & 0.927029 & 0.3550 \\
\hline X1 & -0.017497 & -0.728151 & 0.4673 \\
\hline X2 & 4.467301 & 4.791165 & 0.0000 \\
\hline X3 & 0.453574 & 2.348457 & 0.0198 \\
\hline X4 & -0.479316 & -2.386228 & 0.0179 \\
\hline X5 & -0.017272 & -0.895050 & 0.3718 \\
\hline X6 & 0.075203 & 2.537326 & 0.0119 \\
\hline \multicolumn{4}{|l}{ Source: Processed E-Views 10 } \\
\hline
\end{tabular}

Based on the table above, it can be concluded that Firm Size and Liquidity have no significant effect on firm value partially. Profitability Leverage, Asset Structure, and Company Growth have a significant effect on Company Value partially.

\section{Moderating Regression Analysis (MRA) Test}

Table 8. Moderating Regresion Analysis Test Results

\begin{tabular}{|l|l|l|l|}
\hline Variables & Coefficient & t-Statistic & Prob. \\
\hline $\mathrm{C}$ & 0.631189 & 1,009984 & 0.3386 \\
\hline $\mathrm{X} 1$ & -0.023139 & 3,573893 & 0.3450 \\
\hline $\mathrm{X} 2$ & 5.305465 & $-2,292509$ & 0.0000 \\
\hline $\mathrm{X} 3$ & 0.577692 & 0,213914 & 0.0393 \\
\hline $\mathrm{X} 4$ & -0.781068 & 1,165749 & 0.0078 \\
\hline $\mathrm{X} 5$ & -0.005280 & 0,626393 & 0.8337 \\
\hline $\mathrm{X} 6$ & 0.040525 & 0,791934 & 0.4609 \\
\hline $\mathrm{X} 1 * \mathrm{Z}$ & 0.005957 & 0,022653 & 0.2967 \\
\hline $\mathrm{X} 2 * \mathrm{Z}$ & -1.106788 & 0,061665 & 0.1212 \\
\hline $\mathrm{X} 3 * \mathrm{Z}$ & -0.077466 & $-0,314167$ & 0.7468 \\
\hline $\mathrm{X} 4 * \mathrm{Z}$ & 0.257502 & 0,193607 & 0.1869 \\
\hline $\mathrm{X} 5 * \mathrm{Z}$ & -0.018458 & 0,278779 & 0.5379 \\
\hline $\mathrm{X} 6 * \mathrm{Z}$ & 0.066528 & $-1,172169$ & 0.3833 \\
\hline
\end{tabular}


Based on Table 8 Above, it can be concluded that Intellectual Capital cannot partially moderate the effect of Firm Size, Profitability, Leverage, Asset Structure, Liquidity, and Firm Growth on firm value.

\section{CONCLUSION}

Based on the results of data analysis and research discussion, the following conclusions can be drawn:

1. Firm Size as proxied using Firm Size partially has a negative and insignificant effect on firm value proxied using Price to Book Value (PBV).

2. Profitability proxied using ROA partially has a positive and significant effect on firm value proxied using PBV.

3. Leverage proxied using DTA partially has a positive and significant effect on firm value proxied using PBV.

4. The asset structure of DTA partially has a negative and significant effect on firm value as proxied using PBV.

5. Liquidity proxied using CR partially has a negative and insignificant effect on firm value proxied using PBV.

6. The company's growth as proxied using growth partially has a positive and significant effect on the value as proxied using PBV.

7. Intellectual Capital as proxied using VAICTM does not moderate the relationship between the effect of Firm Size proxied using Firm Size on firm value proxied using PBV.

8. Intellectual Capital as proxied using VAICTM does not moderate the relationship between Profitability proxied using ROA on firm value proxied using PBV.

9. Intellectual Capital as proxied using VAICTM does not moderate the relationship between Leverage proxied using DTA on firm value as proxied using PBV.

10. Intellectual Capital as proxied using VAICTM does not moderate the relationship between the influence of Asset Structure on firm value as proxied using PBV.
11. Intellectual Capital as proxied using VAICTM does not moderate the relationship between Liquidity proxied using $\mathrm{CR}$ on firm value as proxied using PBV.

12. Intellectual Capital as proxied using VAICTM does not moderate the relationship between the effect of Company Growth as proxied using Growth on firm value as proxied using PBV.

\section{LIMITATIONS OF THE RESEARCH}

1. Companies that are members of the Kompas 100 Stock Company are different types of companies (heterogeneous).

2. The moderating variable of intellectual capital used is VAICTM, a combination of 3 components of intellectual capital so that each component can still be tested into individual variables.

\section{SUGGESTION}

1. Further researchers should use companies with the same type of business (homogeneous) to compare companies.

2. Further researchers are advised to make each component of intellectual capital into each variable to determine what components can moderate the dependent variable on the independent variable.

3. Suggestions for companies, managers are expected to be more selective in allocating costs to maximize profits, especially in this case, costs that cannot increase company value, such as intellectual capital. Because based on the study results, it was found that intellectual capital did not moderate in terms of increasing firm value. In this case, the manager must recruit competent employees to improve the quality of employees is no longer needed.

4. It is hoped that investors can use it as a reference in analyzing financial statements published on the IDX. Profitability, leverage and company 
growth need to be considered by investors because they have a positive and significant impact on the company's value, thus guaranteeing promising prospects when investing in the company.

\section{Acknowledgement: None}

\section{Conflict of Interest: None}

\section{Source of Funding: None}

\section{REFERENCES}

1. Brigham, E. F., \& Houston, J. F. (2006). Dasar-Dasar Manajemen Keuangan, Edisi 11. Jakarta: Salemba 4.

2. Brigham, E. F., \& Houston, J. F. (2018). Dasar-Dasar Manajemen Keuangan Edisi 14. Jakarta: Salemba 4.

3. Carstens, R., \& Wesson, N. (2019). The Impact Of South African Real Estate Investment Trust Legislation On Firm Growth And Firm Value. South African Journal Of Economic And Management Sciences, 1015-8812.

4. Chaidir, C. (2015). Pengaruh Struktur Modal, Profitabilitas, Dan Pertumbuhan Perusahaan Terhadap Nilai Perusahaan Pada Perusahaan Sub Sektor Transportasi Yang Tercacat Di Bursa Efek Indonesia Periode 2012-2014. JIMFE| Jurnal Ilmiah Manajemen Fakultas Ekonomi, 2(2).

5. Dessyana. (2016). Faktor-Faktor Yang Mempengaruhi Nilai Perusahaan Pada Perusahaan Manufaktur Yang Terdaftar Di Bursa Efek Indonesia Dengan Profitabilitas Sebagai Variabel Intervening. USU Repository.

6. Dewi, D. A., \& Sudiartha, G. M. (2017). Pengaruh Profitabilitas, Ukuran Perusahaan, Dan Pertumbuhan Aset Terhadap Struktur Modal Dan Nilai Perusahaan. E-Jurnal Manajemen Unud, 2222-2252.

7. Erlina. 2011. Metodologi Penelitian. Medan: USU Press.

8. Fatimah, Mardani, R. M., \& Wahono, B. (2019). Pengaruh Good Corporate Governance Terhadap Nilai Perusahaan Dengan Kinerja Keuangan Sebagai Variabel Intervening (Studi Kasus Pada Perusahaan Manufaktur Sektor Barang Konsumsi Yang Terdaftar Di BEI Tahun 2015-2017). E-
Jurnal Riset Manajemen Prodi Manajemen Fakultas Ekonomi Unisma.

9. Harahap, S. S. (2013). Analisis Kritis Atas Laporan Keuangan. Jakarta: Rajawali Pers.

10. Hermungsingsih, S., \& Wardani, D. K. (2009). Faktor-Faktor Yang Mempengaruhi Nilai Perusahaan Pada Perusahaan Yang Terdaftar Di Bursa Efek Malaysia Dan Di Bursa Efek Indonesia. Jurnal Siasat Bisnis, 173-183.

11. Hermuningsih, S. (2012). Pengaruh profitabilitas, size terhadap nilai perusahaan dengan sruktur modal sebagai variabel intervening. Jurnal siasat bisnis, 16(2).

12. Hutasoit, N. (2016). Analisis Faktor yang Mempengaruhi Nilai Perusahaan Melalui Pengungkapan Corporate Socialresponsibility dengan Intellectual Capital Sebagai Variabel Moderating pada Perusahaan LQ45 yang Terdaftar di Bursa Efek Indonesia. USU Repository.

13. Indriyatni, L. (2012). Analisis Faktor-Faktor Yang Mempengaruhi Nilai Perusahaan Dengan Struktur Modal Sebagai Mediasi Pada Perusahaan Development Property Yang Terdaftar Di Bursa Efek Indonesia 2007-2010. Jurnal Fokus Ekonomi .

14. Jihadi, M., Vilantika, E., Hashemi, S. M., \& Arifin, Z. (2021). The Effect Of Liquidity, Leverage And Profitability On Firm Value: Empirical Evidence From Indonesia. Journal Of Asian Finance Economic And Business, 0423-0431.

15. Kartika, M., \& Hatane, S. E. (2013). Pengaruh Intellectual Capital Pada Profitabilitas Perusahaan Perbankan Yang Terdaftar Di Bursa Efek Indonesia Pada Tahun 2007-2011. Business Accounting Review.

16. Kasmir. (2011). Analisis Laporan Keuangan. Jakarta: Raja Grafindo Persada.

17. Khumairoh, Kalbuana, N., \& Mulyati, H. (2016). Pengaruh Leverage, Profitabilitas Dan Ukuran Perusahaan Pada Perusahaan Garment Dan Textile Terdaftar Di BEI Tahun 2011-2015. Syariah Acccounting FEB UNS, 71-81.

18. Kusumajaya, D. O. (2011). Pengaruh Struktur Modal Dan Pertumbuhan Perusahaan Terhadap Profitabilitas Dan Nilai Perusahaan Pada Perusahaan Manufaktur Di BEI. Tesis Universitas Udayana.

19. Limbong, D., \& Chabachib, M. (2016). Analisis Pengaruh Struktur Modal, 
Muhammad Fahriza Tampubolon et.al. Analysis of factors affecting firm value with intellectual capital as moderating variable in Kompas 100 companies listed on the IDX.

Pertumbuhan Penjualan Dan Ukuran Perusahaan Terhadap Nilai Perusahaan Dengan Profitabilitas Sebagai Variabel Intervening. Diponegoro Journal Of Management, 1-14.

20. Mahendra, A. D. (2012). Pengaruh Kinerja Keuangan Terhadap Nilai Perusahaan Pada Perusahaan Manufaktur Di Bursa Efek Indonesia. Jurnal Manajemen, Strategi Bisnis Dan Kewirausahaan, 125-140.

21. Manoppo, M., Mangantar, M., \& Rate, V. P. (2018). The Effect Of Asset Structure Of Debt Policy On Automotive Company Listed In IDX Period 2012-2016. Jurnal Emba.

22. Noerirawan, M. R., \& Muid, A. (2012). Pengaruh Faktor Internal Dan Eksternal Perusahaan Terhadap Nilai Perusahaan (Studi Empiris Pada Perusahaan Manufaktur Yang Terdaftar Di BEI Periode 2007-2010). Diponegoro Journal Accounting, 1-12.

23. Novari, P. M., \& Lestari, V. P. (2016). Pengaruh Ukuran Perusahaan Dan Leverage Terhadap Nilai Perusahaan Dengan Profitabilitas Sebagai Variabel Mediasi. EJurnal Manajemen Unud, 1338-1367.

24. Nugroho, W. A. (2012). Pengaruh Profitabilitas, Likuiditas Dan Leverage Terhadap Nilai Perusahaan (Studi Kasus Pada Perusahaan Manufaktur Di Bursa Efek Indonesia Periode 2008-2011). Universitas Muhammadiyah Surakarta.

25. Nurhayati, M. (2013). Profitabilitas, Likuiditas Dan Ukuran Perusahaan Pengaruhnya Terhadap Kebijakan Dividen Dan Nilai Perusahaan Sektor Non Jasa. Jurnal Keuangan Dan Bisnis.

26. Olivia, S., \& Hatane, S. E. (2015). Pengaruh Value Added Intellectual Capital Terhadap Kinerja Keuangan Dan Nilai Pasar Perusahaan Khususnya Di Industri Perdagangan Jasa Yang Terdaftar Di Bursa Efek Indonesia Tahun 2008-2013. Business Accounting Review, 3(1), 45-54.

27. Pamungkas, F. A., Wijayanti, A., \& Fajri, R. N. (2020). Pengaruh Struktur Aset, Ukuran Perusahaan, Profitabilitas Terhadap Nilai Perusahaan. Journal Of Economic, Public And Accounting, 86-102.

28. Prasetyorini, B. F. (2013). Pengaruh Ukuran Perusahaan, Leverage, Price Earning Ratio Dan Profitabilitas Terhadap Nilai Perusahaan. Jurnal Imu Manajemen Universitas Negeri Surabaya.
29. Pratama, I. G., \& Wiksuana, I. G. (2016). Pengaruh Ukuran Perusahaan Dan Leverage Terhadap Nilai Perusahaan Dengan Profitabilitas Sebagai Variabel Mediasi. EJurnal Manajemen Universitas Udayana, 5 (2).

30. Prayitno, J. (2007). Analisis Pengaruh Price Earning Ratio, Price To Book Value Ratio, Dan Return On Equity Terhadap Return Saham Padaindustri Real Estate Dan Property Di BEJ (2002-2006). Tesis Magister Manajemen Sekolah Tinggi Ilmu Ekonomi Ipwija.

31. Purnama, H. (2016). Pengaruh Profitabilitas, Kebijakan Hutang, Kebijakan Dividen Dan Keputusan Investasi Terhadap Nilai Perusahaan (Studi Kasus Perusahaan Manufaktur Yang Go Publik Di Bursa Efek Indonesia) PERIODE 2010 - 2014. Jurnal Akuntansi Vol. 4.

32. Rachmawati, D. (2012). Pengaruh Intellectual Capital Terhadap Return On Asset (ROA) Perbankan. Jurnal Akuntansi, 1.

33. Rudangga, I. N., \& Sudiarta, G. M. (2016). Pengaruh Ukuran Perusahaan, Leverage Dan Profitabilitas Terhadap Nilai Perusahaan. E-Jurnal Manajemen Unud, Vol. 5, No.7, 4394 - 4422.

34. Sari, P. R., \& Dwiranda, A. N. (2019). Pengaruh Current Ratio Dan Deb To Equity Ratio Terhadap Profitabilitas Dengan Intellectual Capital Sebagai Pemoderasi. EJurnal Akuntansi Universitas Udayana, 851880.

35. Sari, R., \& Priyadi. (2016). Pengaruh Leverage, Profitabilitas, Size Dan Growth Opportunity Terhadap Nilai Perusahaan. Jurnal Ilmu Dan Riset Manajemen.

36. Setiadharma, S., \& Machali, M. M. (2017). The Effect Of Asset Structure And Firm Size On Firm Value With Capital Structure As Intervening Variable. Journal Of Business \& Financial Affairs.

37. Setiawati, L. W., \& Melliana, L. (2018). Analisis Pengaruh Profitabilitas, Ukuran Perusahaan, Leverage, Dan Pengungkapan Sosial Terhadap Nilai Perusahaan Pada Perusahaan Manufaktur Yang Terdaftar Di Bursa Efek Indonesia Periode 2011--2015. Jurnal Akuntansi, 12(1), 29-57.

38. Shalini, Witya. (2020). Pengaruh Struktur Kepemilikan dan Kinerja Keuangan Terhadap Nilai Perusahaan dengan Kebijakan Dividen Sebagai Variabel 
Muhammad Fahriza Tampubolon et.al. Analysis of factors affecting firm value with intellectual capital as moderating variable in Kompas 100 companies listed on the IDX.

Moderating pada Perusahaan Properti dan Real Estate yang Terdaftar di BEI Periode 2010-2018. Tesis. Universitas Sumatera Utara.

39. Sintyana, I. H., \& Artini, L. S. (2019). Pengaruh Profitabilitas, Struktur Modal, Ukuran Perusahaan Dan Kebijakan Dividen Terhadap Nilai Perusahaan. E-Jurnal Manajemen, 7717-7745.

40. Sutama, D. R., \& Lisa, E. (2018). Pengaruh Leverage Dan Profitabilitas Terhadap Nilai Perusahaan (Studi Pada Perusahaan Sektor Manufaktur Food And Beverage Yang Terdaftar Di Bursa Efek Indonesia). Jurnal Sains Manajemen Dan Akuntansi, 21-39.

41. Suwarno, Puspito, A., \& Qomariah, N. (2016). Studi Pengaruh Profitabilitas, Ukuran Perusahaan Dan Peluang Pertumbuhan Terhadap Nilai Perusahaan Pada Perusahaan Telekomunikasi Indonesia. Prosiding Seminar Nasional Dan Call For Paper. Jember: Universitas Muhammadiyah Jember.

42. Tahu, G. P., \& Susilo, D. D. (2017). Effect Of Liquidity, Leverage And Profitability To The Firm Value (Dividend Policy As
Moderating Variabel) In Manufacturing Company Of Indonesia Stock Exchange. Resource Journal Of Accounting.

43. Wibowo, M. A., \& Yuliana, I. (2020). Profitabilitas Terhadap Nilai Perusahaan Dengan Intellectual Capital Sebagai Variabel Moderasi. Inovator, 9(2), 75-84.

44. Wijaya, B. I., \& Sedana, I. P. (2015). Pengaruh Profitabilitas Terhadap Nilai Perusahaan (Kebijakan Dividen Dan Kesempatan Investasi Sebagai Variabel Mediasi). E-Jurnal Manajemen Unud, Vol.4, No.12, 4477-4500.

45. Yao, S., Wang, J., \& Song, L. (2011). Determinants Of Social Responsibility Disclosure By Chinese Firms. The University Of Nottingham-China Policy Institute, 1-30.

How to cite this article: Tampubolon MF, Erlina, Fachrudin KA. Analysis of factors affecting firm value with intellectual capital as moderating variable in Kompas 100 companies listed on the IDX. International Journal of Research and Review. 2021; 8(8): 650-659. DOI: https://doi.org/10.52403/ijrr.20210886 